Егупов В.А.

\title{
РЕГИСТРАЦИОННЫЙ УЧЕТ КАК ФОРМА ОГРАНИЧЕНИЯ ПРАВА ГРАЖДАН РОССИЙСКОЙ ФЕДЕРАЦИИ НА СВОБОДНОЕ ПЕРЕДВИЖЕНИЕ, ВЫБОР МЕСТА ПРЕБЫВАНИЯ И ЖИТЕЛЬСТВА
}

\begin{abstract}
Аннотация: Объектом исследования данной статьи являются общественные отношения, складывающиеся в области регистрационного учёта граждан Российской Федерации. Предметом исследования являются нормы Конституции Российской Федерации, касающиеся права граждан на свободное передвижение, выбор места пребывания и жительства в Российской Федерации, а также нормы Федерального закона «О праве граждан Российской Федерации на свободу передвижения, выбор места пребывания и жительства в пределах Российской Федерации», которые данное право, на наш взгляд, ограничивают. Основная цель данной статьи - определить сущность и социальное назначение регистрационного учета, проанализировать административно-правовое регулирование регистрационного учета как государственной деятельности по фиксации и обобщению сведений о гражданах, носящих уведомительный характер, вводимой в целях обеспечения необходимых условий для реализации гражданами России своих прав и свобод, а также исполнения обязанностей перед другими гражданами, государством и обществом, а также уяснить целесообразность регистрационного учета как фоормы ограничения конституционных прав граждан Российской Федерации на свободу передвижения, выбора места пребывания и жительства. Основным методом исследования является диалектический подход в сочетании с критическим отношениям к несовершенствам действующего законодательства в сфрере регистрационного учёта. Кроме того, использованы в исследовании сравнительно-правовой и формально-логический методы. Научная новизна статьи заключается в том, что в ней предпринята попытка комплексного анализа положений действующего законодательства в области регистрационного учёта. Основной вывод исследования сводится к следующему: регистрационный учет в демократическом правовом государстве, каким в соответствии с Конституцией РФ является Россия, не должен быть формой ограничения права законопослушных граждан на свободу передвижения, выбор места пребывания и жительства в пределах территории Российской Федерации. Уведомительный характер регистрационного учета должен исключать административную ответственность за отсутствие регистрации по месту пребывания для законопослушных граждан, и обязывать в то же время незамедлительно регистрироваться по месту пребывания лиц без определенного места жительства и потенциально опасных для общества и государства граждан России. Контроль за исполнением такой обязанности должен быть возложен как органы Федеральной миграционной службы Российской Федерации, так и на органы внутренних дел.
\end{abstract}

Ключевые слова: Регистрация, регистрационный учет, жилое помещение, место пребывания, место жительства, внутренняя миграция, орган регистрационного учета, регистрационный режим, свобода передвижения, паспортная система.

Review: The research object is the range of social relations appearing in the sphere of registration of citizens of the Russian Federation. The research subject includes the provisions of the Constitution of the Russian Federation related to the right of citizens of the Russian Federation to freedom of movement and choice of place of stay and residence within the Russian Federation and the provisions of the Federal Law "On the right of citizens of the Russian Federation to freedom of movement and choice of place of stay and residence within the Russian Federation" which, in the author's opinion, restrict the abovementioned right. The purpose of this article is to define the essence and the social function of registration, to analyze administrative-legal regulation of registration as a government activity aimed at fixation and generalization of notifying information about the citizens for the purpose of 


\section{Полицейская деятельность 3 • 2016}

ensuring the necessary conditions for exercising of rights and freedoms by the citizens and fulfilling their duties to other citizens, the state and the society, and clarifying the reasonability of registration as a form of the citizens' constitutional rights to freedom of movement and choice of place of stay and residence restriction. The research methodology is based on the dialectical approach together with the critical analysis of the imperfections of the current legislation in the sphere of registration. Moreover, the author applies the comparative-legal and the formal-logical methods. The scientific novelty of the study consists in the attempt at a complex analysis of the provisions of the current legislation in the sphere of registration. The author concludes that registration in democratic states, which Russia according to its constitution belongs to, shouldn't be a form of restriction of the right of law-abiding citizens to freedom of movement and choice of place of stay and residence within the country. A notifying character of registration should exclude administrative liability for the absence of registration for lawabiding citizens and at the same time it should oblige the persons of no fixed abode and the persons potentially dangerous for the society and the state to register at their place of stay without any delay. The control over the performance of this obligation should be carried out by the Federal Migration Service bodies and the internal affairs bodies.

Keywords: Passport system, freedom of movement, registration system, registration agency, internal migration, place of residence, place of stay, dwelling premise, registration, registration.

$\mathrm{O}$ дной из наиболее важных, на наш взгляд, юридических и социальных проблем в Российской Федерации является проблема свободного передвижения граждан России, свободного выбора места пребывания и жительства в пределах территории Российской Федерации. Связана данная проблема с важнейшим институтом административного права - институтом регистрационного учета граждан России, который вводит на территории Российской Федерации регистрационный режим как совокупность определенных ограничений прав и свобод граждан. Каждый гражданин России обязан регистрироваться не только по месту жительства в жилом помещении, но и по месту пребывания в жилом помещении в случае, если он находится на территории другого субъекта РФ свыше 90 дней под угрозой административной ответственности за отсутствие такой регистрации. Для того чтобы уяснить сущность возникающих в связи с регистрацией проблем, необходимо обратиться к легальным и доктринальным понятиям регистрационного учета как ссреры государственной деятельности, а также к основам правового регулирования регистрации граждан по месту пребывания и по месту жительства.

В соответствии со статьей 2 Закона Российской Федерации от 25 июня 1993 года №5242-1 (ред. от 31.12.2014 г.) «О праве граждан Российской Федерации на свободу передвижения, выбор места пребывания и жительства в пределах Российской Федерации» [12] (далее по тексту Закон РФ №52421), который и является правовой основой института регистрации, регистрационный учет - государственная деятельность по фиксации и обобщению предусмотренных настоящим Законом сведений о регистрации граждан Российской Федерации по месту пребывания, регистрации граждан Российской Федерации по месту жительства, снятии граждан Российской Федерации с регистрационного учета по месту пребывания и снятии граждан Российской Федерации с регистрационного учета по месту жительства в пределах Российской Федерации. Регистрационный учет граждан Российской Федерации имеет уведомительный характер и отражает факты прибытия гражданина Российской Федерации в место пребывания либо место жительства, его нахождения в указанном месте и убытия гражданина Российской Федерации из места пребывания или места жительства.

Таким образом, регистрационный учет представляет собой форму контроля государства за внутренней миграцией населения, а регистрация граждан Российской Федерации по месту пребывания и месту жительства в жилом помещении - это административная обязанность всех граждан, имеющая цель исполнения гражданами своих обязанностей и реализации своих законных прав и интересов.

Как справедливо отмечает А.В. Мыскин, «регистрация в современных российских ус- 
ловиях просто отвечает на вопрос, где государству и другим участникам гражданского оборота можно будет найти человека (по какому адреса местожительства), если этот человек в силу тех или иных причин понадобится» [9, с.42]. По нашему мнению, данная так называемая регистрационная обязанность гражданина Российской Федерации существенно ограничивает право граждан на свободное передвижение, свободный выбор места пребывания и жительства, поскольку указывает ему на необходимость такой регистрации под угрозой административной ответственности (статья $19.15^{1}$ Кодекса РФ об административных правонарушениях [6] (далее по тексту КоАП РФ)). Поэтому, несмотря на указанный в Законе РФ №5242-1 уведомительный характер регистрационного учета, на практике регистрационный учет сейчас мало отличается от прописки, которая существовала во времена СССР. Нельзя не согласиться с указанием ряда ученых на то, что основной причиной слабого отличия прописки и регистрации являются серьезные противоречия, имеющие место в законодательстве о регистрационном учете, базирующиеся на отношении законодателя к регистрации как средству регулирования миграции, что придает регистрационному учету разрешительный характер [11].

Анализируя институт регистрационного учета О.В. Панкова отмечает, что личному праву граждан России свободно передвигаться корреспондирует обязанность государства по его обеспечению, при реализации этого права неизбежно возникают административно-правовые отношения с государственными и иными уполномоченными органами, и в первую очередь правоотношения, возникающие при осуществлении регистрационного учета $[10$, c.57]. Она же, на наш взгляд, дает самое удачное определение регистрационного учета, под которым понимается ею «специальный учет граждан по месту пребывания и месту жительства, носящий уведомительный характер, осуществляемый в установленном законом порядке органами регистрационного учета, подтверждающий фракт нахождения лица в определенном месте, в котором он пребывает или проживает, и направленный на обеспечение необходимых условий для реализации гражданами их прав и свобод, исполнения ими обязанностей перед другими гражданами, государством и обществом» [10, с.72].

Таким образом, регистрационный учет на законодательном уровне все же, несмотря на благие цели, ограничивает право российских граждан на свободное передвижение по своей стране, создает им неудобства, связанные с необходимостью регистрации по месту пребывания на территории любого субъекта РФ, В котором они не зарегистрированы по месту жительства в жилом помещении.

В свою очередь В.В. Ивановский указывал, что история развития права свободного передвижения связана с постепенным ослаблением ограничений, устанавливаемых в его отношении государством. Оно возникло из ограничений, которые практиковались в эпоху абсолютного и полицейского государства. Эти ограничения выливались в систему мероприятий, известных под именем паспортной системы, имевшей целью наблюдение за передвижением граждан для охраны целости государственного порядка [4, с.258-259]

Схожей точки зрения придерживался А.А. Кауфрман, который, на наш взгляд, абсолютно справедливо отмечал, что «исторически государство стремилось не создавать возможности свободного перемещения населения, а искать способы воздействия на миграционные процессы. Переселение следует рассматривать как фракт, и вся переселенческая политика должна быть направлена, с одной стороны, к тому, чтобы облегчить переселение, с другой стороны, чтобы по возможности уменьшить число желающих переселяться. Для этой цели хороши все способы, кроме запрещения и принуждения» [5, с.349].

С.Ю. Миролюбова в своей монографии отмечает, что «государству было невыгодно признавать право на свободу передвижения в качестве естественного права, так как именно надзор за передвижением населения давал государству возможность его учета и удержания в определенном месте. Ограничение свободы передвижения и разрешительный порядок перемещения по территории Советской России, по сути, носили экономический характер и обеспечивали государству решение следующих основных задач: 1) воинского учета 2) налогообложения 3) управления социально-экономической сферой» $[8$, с.27]. 
В настоящее время изменилось немногое. Государство посредством регистрационного учета легально ограничивает право на свободное перемещение по Российской Федерации, воздействуя таким образом на процесс внутренней миграции населения и наблюдая за перемещение своих же граждан. Запретить переселяться государство не может, принудить к переселению тоже, поэтому наиболее оптимальным вариантом здесь и является обязательность регистрации российских граждан по месту пребывания и месту жительства, причем не где-нибудь, а в жилом помещении. Неисполнение данной обязанности влечет административную ответственность в соответствии со статьей $19.15^{1}$ КоАП РФ [6], нарушители подвергаются административному штрафу.

Регистрационный учет является важнейшим элементом паспортно-регистрационной системы, сложившейся на территории Российской Федерации с давних времен, с появлением первых документов, удостоверяющих личность. По мнению большинства авторов, паспортно-регистрационная система представляет собой совокупность общественных отношений, возникающих между органами Федеральной миграционной службы Российской Федерации и гражданами, и определяющих порядок выдачи, обмена, сдачи и изъятия паспортов граждан Российской Федерации и иных документов, удостоверяющих личность, порядок регистрационного учета граждан по месту пребывания и жительства в целях реализации конституционных прав и свобод, исполнения ими всей совокупности обязанностей, а также охраны общественного порядка, обеспечения государственной и общественной безопасности. Данную точку зрения можно встретить в работах А.П. Коренева [1, с.163], И.В. Черепановой [13, с.10], Л.В. Ивановой [3], Д.Н. Бахраха [2, с.108]

На наш взгляд, вышеуказанные цели регистрационного учета и одновременно реализация конституционного права каждого гражданина Российской Федерации на свободу передвижения, свободу выбора места пребывания и жительства без создания для законопослушных граждан неудобств регистрации будут достигнуты только тогда, когда государство отменит на законодательном уровне обя- занность регистрации по месту пребывания, оставив в силе обязанность каждого гражданина зарегистрироваться по месту жительства в жилом помещении. Регистрация по месту пребывания для законопослушных граждан, по нашему мнению, вообще не должна существовать, её необходимо ввести лишь для отдельных категорий социально опасных граждан (лиц, ранее судимых за тяжкие и особо тяжкие преступления, лиц, состоящих на учете в наркологическом или психоневрологическом диспансере, лиц, страдающими туберкулезом, ВИЧ-инфицированных граждан, лиц, ведущих бродяжнический или антиобщественный образ жизни и т.д.). Тогда и цели регистрационного учета будут оправданы, поскольку перемещение отдельных категорий потенциально опасных российских граждан должно контролироваться государством в целях недопущения последними совершения преступления и иных антиобщественных деяний при нахождении их в других регионах страны. Причем регистрироваться по месту пребывания они должны не по истечении 90 дней, а незамедлительно по прибытии их на территорию субъектов РФ, где они постоянно не проживают.

Таким образом, регистрационный учет в демократическом правовом государстве, каковым в соответствии со статьей 1 Конституции Российской Федерации [7] является Россия, не должен быть формой ограничения права законопослушных граждан на свободу передвижения, выбор места пребывания и жительства в пределах территории Российской Федерации. Уведомительный характер регистрационного учета должен исключать административную ответственность за отсутствие регистрации по месту пребывания для законопослушных граждан, и обязывать в то же время незамедлительно регистрироваться по месту пребывания лиц без определенного места жительства и потенциально опасных для общества и государства граждан России. В случае отсутствия жилого помещения как места регистрации, такая регистрация должна быть проведена по месту нахождения, например, органа местного самоуправления, куда прибыл гражданин России, подлежащий обязательной регистрации по месту пребывания. 


\section{Библиография:}

1. Административная деятельность органов внутренних дел. Часть особенная. / Под редакцией А.П. Коренева. М., 1997.

2. Бахрах Д.Н. Административное право России. М., 2000.

3. Иванова Л.В. Паспортно-визовая служба МВД России: регистрация граждан по месту пребывания и по месту жительства. Домодедово, 2001.

4. Ивановский В.В. Учебник государственного права. Издание 4. Казань, 1913.

5. Кауфрман А.А. Переселение и колонизация. Санкт-Петербург, 1905.

6. Кодекс Российской Федерации об административных правонарушениях от 30.12.2001 N 195-ФЗ (ред. от 04.11.2014). // Российская газета, N 256 от 31.12.2001.

7. онституция Российской Федерации. Принята на всенародном голосовании 12 декабря 1993 г. (с поправками от 30 декабря 2008 г.) // Российская газета. - 21.01.2009.

8. Миролюбова С.Ю. Право на свободу передвижения в пределах Российской Федерации: конституционно-правовой аспект. Монография. Издательство Статут, 2013.

9. Мыскин А.В. Вчера была прописка. Сегодня регистрация. А что изменилось? «Нотариус». 2014. №1.

10. Панкова О.В. Административно-правовое регулирование регистрации граждан Российской Федерации по месту пребывания и месту жительства в пределах РФ: диссертация кандидата юридических наук. М., 2006.

11. Сосновская Ю.Н. Административно-правовые средства обеспечения паспортно-регистрационной системы в Российской Федерации. Диссертация кандидата юридических наук. - М., 2003.

12. Федеральный закон от 25 июня 1993 г. №5242-1 (ред. от 31.12.2014 г.) «О праве граждан Российской Федерации на свободу передвижения, выбор места пребывания и жительства в пределах Российской Федерации». // Российская газета, N 152, 10.08.1993.

13. Черепанова И.В. Регистрация граждан по документам, удостоверяющим личность (теоретический анализ и практика применения). Автореферат диссертации кандидата юридических наук. М., 1999.

\section{References (transliterated):}

1. Bakhrakh D.N. Administrativnoe pravo Rossii. M., 2000.

2. Ivanova L.V. Pasportno-vizovaya sluzhba MVD Rossii: registratsiya grazhdan po mestu prebyvaniya i po mestu zhitel'stva. Domodedovo, 2001.

3. Ivanovskii V.V. Uchebnik gosudarstvennogo prava. Izdanie 4. Ka-zan', 1913.

4. Kaufman A.A. Pereselenie i kolonizatsiya. Sankt-Peterburg, 1905.

5. Mirolyubova S.Yu. Pravo na svobodu peredvizheniya v predelakh Rossiiskoi Federatsii: konstitutsionnopravovoi aspekt. Monografiya. Izdatel'stvo Statut, 2013.

6. Myskin A.V. Vchera byla propiska. Segodnya registratsiya. A chto izmenilos'? «Notarius». 2014. №1.

7. Pankova O.V. Administrativno-pravovoe regulirovanie registratsii grazhdan Rossiiskoi Federatsii po mestu prebyvaniya i mestu zhitel'stva v predelakh RF: dissertatsiya kandidata yuridicheskikh nauk. M., 2006.

8. Sosnovskaya Yu.N. Administrativno-pravovye sredstva obespecheniya pasportno-registratsionnoi sistemy v Rossiiskoi Federatsii. Dissertatsiya kandidata yuridicheskikh nauk. - M., 2003.

9. Cherepanova I.V. Registratsiya grazhdan po dokumentam, udostoveryayushchim lichnost' (teoreticheskii analiz i praktika primeneniya). Avtoreferat dissertatsii kandidata yuridicheskikh nauk. M., 1999. 